\title{
Correction to: Big Surprises: Jackpot Reinforcers in Research and Practice
}

\author{
Kennon A. Lattal ${ }^{1,2}$
}

Published online: 2 December 2020

(C) Association for Behavior Analysis International 2020

\section{Correction to: Behav Analysis Practice}

https://doi.org/10.1007/s40617-020-00423-0

The article was updated to correct errors in the Article Note that were introduced by the Publisher.

Publisher's Note Springer Nature remains neutral with regard to jurisdictional claims in published maps and institutional affiliations.

The online version of the original article can be found at https://doi.org/ 10.1007/s40617-020-00423-0

Kennon A. Lattal

klattal@wvu.edu

1 Osaka Kyoiku University, Osaka, Japan

2 Present address: West Virginia University, Morgantown, WV, USA 